\title{
The Importance of Highlighting Developmental Services During Orientation and Transition
}

\author{
Eric D. Malmberg and John P. Eddy
}

Orientation directors and teachers of first-year courses have a unique responsibility to highlight specialized developmental support services available to students. Even topranked students can often improve their writing, listening, and research abilities by utilizing campus services. Nonetheless, these valuable services are often overlooked or not given the attention they need during orientation and transition.

College and university offices of student affairs place intentional emphasis on providing opportunities for students to develop intellectually, personally, morally, and one of their primary goals is to complement the educational curriculum at the college or university. Developmental services in higher education are essential in meeting that goal. At many colleges and universities, these development services have helped thousands of students to succeed.

Astin (1985) reminds us that, "Students learn by becoming involved" (p. 133) and developmental services can be a model for positive interaction with university faculty and staff. Research by Pascarella \& Terenzini (1991) indicates that students exposed to specialized services for instruction in academic skills, advising and counseling programs, comprehensive support services, and remedial or developmental studies, attain higher grade point averages and retention rates than those who are not. The overall effect is greatest during the freshman year, and students who utilize university writing centers, math labs, speech and hearing centers, counseling and testing centers, mentoring, supplemental instruction, and study skills services increase their ability to succeed in college.

Following is a partial list of retention services that should be emphasized during an orientation program. Of course, most campuses will have other such services that will need to be equally highlighted.

\section{Developmental Services}

\section{Writing Centers}

Many writing centers provide free tutoring and workshops for all students — freshman through graduate levels. Experienced tutors typically provide individual and group work in areas such as punctuation, grammar, and essay writing. These centers may also operate "Grammar/Writing Hotlines," which encourage faculty, students, and staff to use

Eric D. Malmberg is a doctoral student at the University of North Texas and John P. Eddy, Ph.D., is a Professor of Higher Education at the University of North Texas. 
the service for questions about writing format.

\section{Speech and Hearing Centers}

Speech and hearing centers routinely test students to determine if they have any speech or hearing difficulties. These centers are usually open to students free of charge and provide professional assistance in helping patients to overcome their oral language and dialect problems. Some specialized speech centers assist students to overcome disorders of fluency, voice, articulatory, developmental language, and other services. Audiology clinics offer, among other services, peripheral and central hearing testing and screening, and testing for central auditory processing disorder testing.

\section{Counseling Centers}

Counseling and testing services provide psychological services to assist students in identifying, assessing, and resolving concerns that may interfere with their academic, social, career, and emotional growth and development. Counseling centers vary in their approaches; some are more developmental while others are more therapeutic. Some offer vocational education, testing assistance, and evaluation for the presence of learning disabilities and attention-deficit and hyperactivity. These services are designed to help students achieve their educational goals, learn the process of problem solving and decision making, develop and understand the value of relationships, and learn to make full use of their potentials.

\section{Career Centers}

Centers for career choice and guidance offer a wide range of programs and services designed to assist students in the process of identifying, selecting, and pursuing appropriate career goals. This includes interest and aptitude assessment, career counseling, selfadministered computerized career interest exploration, student employment, internships, interview training, resume writing clinics, electronic resume distribution, and a library of catalogs and career information. Much of the data is computerized and readily accessible to students.

\section{Study Skills Services}

Many institutions provide tutoring and study skills programs to help students "learn how to study," as well as assist with academic problems and referrals for advice about the future. Special services provide student counseling, mentoring, tutoring, seminars, supplemental instruction and scholarship assistance. Centers for academic success provide special assistance in computerized tutorial programs and assessment, and some institutions administer more targeted programs. 


\section{Mentoring}

Mentoring can provide students with career information and guidance, help in deciding a major, guidance for success in college, and friendly encouragement. Those identified to be mentors might include upper-class students, faculty, staff, alumni, or community leaders. They typically are invited to attend special training opportunities throughout the year. Mentoring relationships are structured so that both the mentor and the person being mentored benefit from the process.

\section{Conclusion}

Upcraft and Schuh (1996) found that one way of measuring student satisfaction with their overall experience at a college or university is to determine the extent to which they persist from year to year and finally to graduation. Developmental services designed to identify and remove learning barriers are essential for student development. These services have helped thousands of students to succeed and enhance the performance level of thousands more.

While the above listings are not intended to be all-inclusive, they are meant as a reminder of the importance of making certain that orientation students are well-versed on and comfortable in seeking out these services. Orientation directors and first-year advisors are in the throes of planning for next year's efforts, and it is important to evaluate whether their programs highlight and encourage developmental services. Orientation and transition are, after all, much more than a few summer days and afternoon classes; they are the global undertaking of student satisfaction and retention efforts for each new student.

\section{References}

Astin, A. (1985). Achieving academic excellence: A critical assessment of priorities and practices in higher education. San Francisco: Jossey-Bass.

Pascarella, E. T., \& Terenzini, P. T. (1991). How college affects students: Findings and insights from twenty years of research. San Francisco: Jossey-Bass.

Upcraft, M. L. \& Schuh, J. H. (1996). Assessment in student affairs: A guide for practitioners. San Francisco: Jossey-Bass. 